\title{
The changing trends in epidemiological characteristics of gastric adenocarcinoma: a Tunisian center experience
}

\author{
Rafik Ghrissi $^{1}{ }^{*}$, Mohamed amine Elghali ${ }^{1}$, Rim Ghammam $^{2}$, Amine Gouader $^{1}$, Fehmi Hamila $^{1}$, \\ Mohamed Rached Letaief ${ }^{1}$
}

\author{
${ }^{1}$ Department of General Surgery, Farhat Hached University Hospital, Sousse, Tunisia \\ ${ }^{2}$ Department Hospital Hygiene and Preventive Medicine, Farhat Hached University Hospital, Sousse, Tunisia
}

Received: 02 November 2015

Revised: 07 November 2015

Accepted: 18 November 2015

\section{*Correspondence:}

Dr. Rafik Ghrissi,

E-mail: ghrissirafik@yahoo.fr

Copyright: (C) the author(s), publisher and licensee Medip Academy. This is an open-access article distributed under the terms of the Creative Commons Attribution Non-Commercial License, which permits unrestricted non-commercial use, distribution, and reproduction in any medium, provided the original work is properly cited.

\begin{abstract}
Background: Gastric adenocarcinoma is a frequent disease characterized by recent changing trends in epidemiological features, mainly in developed countries. The aim of our study is to describe any changing trends, mainly, in distal and proximal gastric adenocarcinomas rates and signet ring cells adenocarcinomas rate.

Methods: This is a retrospective monocentric study of 169 consecutive cases of primary invasive gastric adenocarcinoma, covering a period of 20 years. We have divided these cases into 2 equal-period groups. The rates of proximal cancers (cardia cancers), distal cancers (non-cardia cancers) and signet ring cells adenocarcinomas had been compared. Other parameters have been studied and compared such as gender, age and surgery types.

Results: There is a statistically significant difference between the 2 groups regarding the rates of signet ring cells adenocarcinoma. The cardia cancer rates and non-cardia cancer rates are not statistically different between the 2 groups $(\mathrm{p}=0.074)$. However, there is an increasing trend in cardia cancers rate $(7.6 \%$ to $16.7 \%)$ and a decreasing in non-cardia cancers rate $(92.4 \%$ to $83.3 \%)$. There is no difference in regards to age, sex and type of surgery.

Conclusions: The database of our retrospective study regarding age $\&$ sex incidence, clinicopathological features and therapeutic outcome was comparable to other studies in various literatures.
\end{abstract}

Keywords: Gastric adenocarcinoma, Cardia tumors, Non-cardia tumors, Signet ring cells adenocarcinoma, Epidemiology

\section{INTRODUCTION}

Adenocarcinoma of the stomach is a common disease posing a global health problem. Its epidemiological characteristics are changing in some countries, especially in developed countries. Indeed, its incidence is decreasing in recent years, which is explained by a decrease in rates of distal gastric cancers. ${ }^{1-3}$ Also, there is an increase in rates of signet ring cells (SRC) adenocarcinoma in developed countries. ${ }^{4}$ However, it is important to know if these changes interest other regions, especially North African countries. The objective of our study is, in fact, to analyze possible changing trends in the epidemiological features of this disease in our area.

\section{METHODS}

This is a retrospective monocentric study of consecutive cases of primary invasive gastric adenocarcinoma treated at the university hospital Farhat Hached of Sousse, during a 20-year period, ranging from September 1995 to August 2015. It has recorded 169 cases, which have been 
divided into 2 groups of equal periods: the first group (group 1) includes cases observed between September 1995 and August 2005; and the 2nd group (group 2) includes cases observed between September 2005 and August 2015. We have chosen to do a comparison between the 2 groups regarding the following parameters:

1. Distal and proximal cancers rates.

2. SRC adenocarcinomas rates.

3. Type of surgery.

4. Age.

5. Gender.

Anatomical sub site was specified according to the WHO (World Health Organization) classification: cardia, fundus, corpus, antrum, pylorus, lesser curvature, greater curvature, overlapping and unspecified. Non-cardia sub sites (distal cancers) were considered to include fundus, corpus, antrum, pylorus, lesser and greater curvatures. Proximal cancers include cardia tumors.

The statistical analysis of the data was carried out using SPSS 20 software. Chi-square test of Pearson was used to compare the above mentioned parameters, excepting the parameter 'age' when a Student test was used.

$\mathrm{p}$ values $<0.05$ were regarded to be statistically significant.

\section{RESULTS}

There are 79 cases in group 1, and 90 cases in group 2.

The average age was 63.04 years in group 1 (standard deviation: 9.011 years) and 60.24 years in group 2 (standard deviation: 9.419 years), with no significant difference $(\mathrm{p}=0.051)$. The median age is 66 years in group 1 and 61.5 years in group 2. There were 53(67.1\%) men in group 1 versus $58(64.4 \%)$ men in group 2.

We have collected 6 cases $(7.6 \%)$ of cardia tumors and 73 cases $(92.4 \%)$ of non-cardia tumors, in group1, versus 15 cases $(16.7 \%)$ of cardia tumors and 75 cases $(83.3 \%)$ of non-cardia tumors in group 2. The difference is not statistically significant $(\mathrm{p}=0.0704)$. There were no cases of undefined or overlapping anatomical sub site.

In group 1, 48patients (60.8\%) had a subtotal gastrectomy and 23patients $(29.1 \%)$ underwent total gastrectomy, versus 40 cases $(44.4 \%)$ of subtotal gastrectomy and 38 cases $(42.2 \%)$ of total gastrectomy, in group 2 .

On the other hand, we identified 9 cases (11.4\%) of SRC adenocarcinomas, and 70 cases $(88.6 \%)$ of intestinal subtype adenocarcinomas, in group 1; versus 21 cases (23.3\%) of SRC adenocarcinomas and 69 cases $(76.7 \%)$ of intestinal subtype adenocarcinoma in group 2. The difference is statistically significant $(\mathrm{p}=0.043)$.
Table 1: Comparison between two groups with different parameters.

\begin{tabular}{|c|c|c|c|}
\hline Parameters & $\begin{array}{l}\text { Group } 1 \\
\text { (Numbe } \\
\text { r: } 79 \text { ) }\end{array}$ & $\begin{array}{l}\text { Group } 2 \\
\text { (Number } \\
: 90)\end{array}$ & $\mathbf{P}$ \\
\hline Age (average age) & 63.04 & 60.24 & 0.051 \\
\hline $\begin{array}{l}\text { Gender } \\
\text { Male } \\
\text { Female }\end{array}$ & $\begin{array}{l}53 \\
(67.1 \%) \\
26 \\
(32.9 \%)\end{array}$ & $\begin{array}{c}58 \\
(64.4 \%) \\
32(35.6 \%) \\
\end{array}$ & 0.718 \\
\hline \multicolumn{4}{|c|}{ Adenocarcinoma site } \\
\hline Distal & $\begin{array}{l}73 \\
(92.4 \%) \\
\end{array}$ & $\begin{array}{l}75 \\
(83.3 \%)\end{array}$ & $0.074 * *$ \\
\hline Proximal & $6(7.6 \%)$ & $\begin{array}{l}15 \\
(16.7 \%)\end{array}$ & \\
\hline \multicolumn{4}{|l|}{ Histological type } \\
\hline Intestinal subtype & $\begin{array}{l}70 \\
(88.6 \%)\end{array}$ & $\begin{array}{l}69 \\
(76.7 \%)\end{array}$ & $0.043^{*}$ \\
\hline $\begin{array}{l}\text { SRC } \\
\text { adenocarcinoma }\end{array}$ & $\begin{array}{c}9 \\
(11.4 \%)\end{array}$ & $\begin{array}{l}21 \\
(23.3 \%)\end{array}$ & \\
\hline \multicolumn{4}{|l|}{ Surgery } \\
\hline None & $\begin{array}{c}8 \\
(10,1 \%)\end{array}$ & $\begin{array}{l}12 \\
(13.3 \%)\end{array}$ & 0.104 \\
\hline $\begin{array}{l}\text { Total gastrectomy } \\
\text { Subtotal } \\
\text { gastrectomy }\end{array}$ & $\begin{array}{l}23 \\
(29.1 \%) \\
48 \\
(60.8 \%)\end{array}$ & $\begin{array}{l}38 \\
(42.2 \%) \\
40 \\
(44.4 \%)\end{array}$ & \\
\hline
\end{tabular}

*: difference statistically significant

**: difference tends to be statistically significant

\section{DISCUSSION}

Adenocarcinomas are the most common histological type of gastric cancers. They affect men more than women, both in Africa than in other continents, thing that stands out in our study. However, the male predominance remains stable and comparable between our 2 groups. Gastric cancer occurs rarely before the age of 40; the incidence increases rapidly beyond, peaking in the seventh decade. ${ }^{\mathbf{5}}$ This was verified in our study, but there was no change between the two groups regarding this parameter.

Gastric adenocarcinomas are anatomically classified as distal cancers (non cardia cancers) and proximal cancers (also referred as gastro-esophageal junction cancers or cardia cancers). Because non cardia cancers constitute the majority of stomach cancer cases worldwide, overall stomach cancer incidence rates are predominated by this disease entity. The incidence is in decline during the past years, in developed countries. ${ }^{1}$ However, stomach cancer remains one of the ten world causes of mortality for cancer. ${ }^{6}$ Indeed, it is the fourth most common type of cancer and the second most common among cancer deaths worldwide. ${ }^{7-9}$ Its incidence is characterized by a significant geographic disparity; indeed, across continents, incidence rates vary from 3.4 per 100,000 PY among females in North America to 26.9 per 100,000 PY 
among males in Asia. ${ }^{10-12}$ Africa is a low risk area of gastric cancer. However, a meta-analysis of gastric cancer in Africa has shown a clear increase in the incidence of this cancer in Mali (20.3 / 100,000) compared to other African countries, and a higher incidence increased in Sub Saharan Africa compared to North Africa. ${ }^{13}$ In Tunisia (North African country) the incidence is low; it is 5.8/100,000 in men and 3.7/100,000 in women. ${ }^{14}$ But there is no recent Tunisian or North African study analyzing the trends in incidence and epidemiological features of gastric cancer. Through many world regions, there is a decrease in its incidence, which has been described for many years in developed countries. It has been explained by a decrease in the rate of distal cancers relative to a steady rate or even increased of proximal cancers. $^{2,3,15-19}$ An account of the trends in the USA gathered from the Surveillance, Epidemiology and End Results (SEER) data between 1977 and 2006 revealed a decline in the rate of non-cardia carcinomas among all race and age groups except for whites aged 25-39 years, where an increase in incidence rate was seen. ${ }^{20}$ The cardia cancers and non-cardia cancers clearly vary in incidence trends, geographical distribution, proposed etiology, clinical presentation and treatment strategies. ${ }^{21}$ Risk factors for non-cardia cancers include Helicobacter pylori infection, low socioeconomic status, smoking, intake of salty and smoked food, and low consumption of fresh fruits and vegetables. ${ }^{22-31}$

The decrease in incidence of non-cardia cancers likely reflects a diminishing prevalence of Helicobacter pylori infection due to improved sanitation, increasing availability of fresh fruits and vegetables, and decreasing use of salt- and smoke-based food preservation methods. In contrast to non-cardia cancers, incidence rates of cardia cancers have either increased or remained constant in Western countries. ${ }^{2,15,32}$ Risk factors for cardia cancer include male sex, white race, smoking, obesity, and gastroesophegeal reflux. ${ }^{16,33-35}$ The association between Helicobacter pylori and cardia cancer is unclear, but it may have a protective effect in the onset of this cancer. ${ }^{36}$

In our study, we can say that results are close to those of the Western studies. Indeed, although the difference is not statistically significant, we have noticed, anyway, a decrease in the rate of distal cancers $(92.4 \%$ to $83.3 \%)$ against an increase in the rate of proximal cancers $(7.6 \%$ to $16.7 \%$ ). Also, there is no statistically significant change in gastrectomies rates between the 2 groups. However, the increasing and decreasing rates of simultaneous total and subtotal gastrectomies may reflect changes' results in distal, proximal and SRC cancers' rates. Larger studies, with bigger samples, are necessary for better exploring trends in these rates.

On another side, regarding histological features, there are two classifications for gastric adenocarcinomas:

A. WHO classification: gastric cancer is classified according to differentiation category into:
1. Papillary adenocarcinoma composed of epithelial digitiform protrusions with fiber axes.

2. Tubular adenocarcinoma, consisting of branched tubules included in a fibrous stroma.

3. Mucinous adenocarcinoma which more than $50 \%$ of the cells appear on smaller groups floating in mucin lakes.

4. SRC adenocarcinoma having a predominant contingent (more than $50 \%$ of the tumor) of isolated cells or small cell groups dispersed in a fibrous stroma, with intracytoplasmic mucin.

B. Lauren classification, often used by epidemiologists, distinguishes only two categories:

1. Intestinal type is a differentiated cancer.

2. Diffuse type, corresponds to an undifferentiated cancer.

Epidemiologically, it is considered that the differentiated type is more related to Helicobacter pylori infection than the diffuse type. ${ }^{37,38}$

The combined use of these two classifications is causing confusion concerning the interpretation of some study results; the SRC type in the WHO classification is usually associated with diffuse histological type of Lauren classification. Thus the results of several studies analyzing the clinical characteristics and prognostic value of diffuse type adenocarcinoma were extrapolated to SRC adenocarcinoma. However, although the SRC adenocarcinoma is part of all diffuse tumors, it is important to note that all of the diffuse type tumors are not SRC adenocarcinoma. ${ }^{39}$

The interest of these classifications is to distinguish the histological types, of which epidemiological characteristics are different. Henson et al. have observed that the specific incidence of SRC adenocarcinomas, and to a lesser degree diffuse type, was increasing, in contrast to the overall incidence of gastric adenocarcinoma; thus suggesting that these histological types have different pathogenesis and distinct risk factors.

In addition, in a French multicenter study published in 2015, involving 1799 cases of gastric adenocarcinoma, the rate of SRC adenocarcinomas was high reaching 50\% of all gastric adenocarcinoma cases. These SRC cancers mainly affect young women with family background of cancer (such as Lynch syndrome). ${ }^{40}$

In our study, we noticed a rise in the SRC adenocarcinoma rate in group 2 compared to group 1 , against a decrease in the rate of intestinal subtype adenocarcinoma. The difference is statistically significant. This certainly reflects a difference between the risk factors of these two entities. 


\section{CONCLUSION}

The changes in epidemiological characteristics of stomach cancers are checked in developed countries and seem being confirmed in other countries especially in North African region. Subsequent studies, focusing on the study of risk factors, are needed to analyze the causes of these changes.

Funding: No funding sources Conflict of interest: None declared

Ethical approval: The study was approved by the institutional ethics committee

\section{REFERENCES}

1. Muñoz N, Franceschi S. Epidemiology of gastric cancer and perspectives for prevention. Salud Publica Mex. 1997;39:318-30.

2. Devesa SS, Fraumeni JF Jr. The rising incidence of gastric cardia cancer. J Natl Cancer Inst. 1999;91:747-9.

3. Brown LM, Devesa SS. Epidemiologic trends in esophageal and gastric cancer in the United States. Surg Oncol Clin N Am. 2002;11:235-56.

4. Henson DE, Dittus C, Younes M, and Nguyen H, Albores-Saavedra J. Differential trends in the intestinal and diffuse types of gastric carcinoma in the United States-2000: increase in the signet ring cell type. Arch Pathol Lab Med. 2004;128:765-70.

5. Aparicio T, Yacoub M, Karila-Kohen P, René E. Adénocarcinome gastrique : notions fondamentales, diagnostic et traitement. EMC. 2004;1(1):1-84.

6. Lin Y, Ueda J, Kikuchi S, Totsuka Y, Wei WQ, Qiao YL et al. Comparative epidemiology of gastric cancer between Japan and China. World J Gastroenterol. 2011;17(39):4421-8.

7. Parkin DM, Bray F, Ferlay J, Pisani P. Global cancer statistics, 2002. CA Cancer J Clin. 2005;55(2):74108.

8. Schlansky B, Sonnenberg A. Epidemiology of Noncardia Gastric Adenocarcinoma in the United States. Am J Gastroenterol. 2011;106(11):1978-85.

9. Parkin DM, Bray FI, Devesa SS. Cancer burden in the year 2000: the global picture. Eur J Cancer. 2001;37(Suppl 8):S4-66.

10. Kamangar F, Dores GM, Anderson WF. Patterns of cancer incidence, mortality, and prevalence across five continents: defining priorities to reduce cancer disparities in different geographic regions of the world. J Clin Oncol. 2006;24:2137-50.

11. Devesa SS, Silverman DT. Cancer incidence and mortality trends in the United States: 1935-74. J Natl Cancer Inst. 1978;60:545-71.

12. Nomura A. Stomach cancer. In: Schottenfeld D, Fraumeni JF Jr, eds. Cancer epidemiology and prevention. 2nd ed. New York (NY): Oxford University Press. 1996:707-24.
13. Asombang AW, Kelly P. Gastric cancer in Africa: what do we know about incidence and risk factors. Trans R Soc Trop Med Hyg. 2012;106(2):69-74.

14. Institut national de santé publique. Registre des cancers Nord-Tunisie. Données 2004-2006. Available at: http://www.insp.rns.tn/doc/cancer/cancer17.pdf

15. Blot WJ, Devesa SS, Kneller RW, Fraumeni JF Jr. Rising incidence of adenocarcinoma of the esophagus and gastric cardia. JAMA. 1991;265:1287-9.

16. Devesa SS, Blot WJ, Fraumeni JF Jr. Changing patterns in the incidence of esophageal and gastric carcinoma in the United States. Cancer. 1998;83:2049-53.

17. Powell J, McConkey CC. The rising trend in oesophageal adenocarcinoma and gastric cardia. Eur J Cancer Prev 1992;1:265-9.

18. McKinney A, Sharp L, Macfarlane GJ, Muir CS. Oesophageal and gastric cancer in Scotland 1960-90. Br J Cancer. 1995;71:411-5.

19. Moller H. Incidence of cancer of oesophagus, cardia and stomach in Denmark. Eur $\mathrm{J}$ Cancer Prev. 1992;1:159-64.

20. Anderson WF, Camargo MC, Fraumeni JF Jr, Correa P, Rosenberg PS, Rabkin CS. Age-specific trends in incidence of noncardia gastric cancer in US adults. JAMA. 2010;303:1723-8.

21. Van Cutsem E, Dicato M, Geva R, Arber N, Bang Y, Benson A et al. The diagnosis and management of gastric cancer: expert discussion and recommendations from the $12^{\text {th }}$ ESMO/World Congress on Gastrointestinal Cancer, Barcelona, 2010. Annals of Oncology. 2011;22(Supplement 5):v1-9.

22. Helicobacter and Cancer Collaborative Group. Gastric cancer and Helicobacter pylori: A combined analysis of 12 case control studies nested within prospective cohorts. Gut. 2001;49:347-53.

23. Smith GD, Hart C, Blane D, Hole D. Adverse socioeconomic conditions in childhood and cause specific adult mortality: Prospective observational study. Bmj. 1998;316:1631-5.

24. Van Loon AJ, Brug J, Goldbohm RA, Van den Brandt PA. Differences in cancer incidence and mortality among socio-economic groups. Scand J Soc Med. 1995;23:110-20.

25. Mellouki I, laazar N, Benyachou B, Aqodad N, Ibrahimi A. Epidémiologie du cancer gastrique: expérience d'un centre hospitalier marocain. Pan African Medical Journal. 2014;17:42.

26. Trédaniel J, Boffetta P, Buiatti E, Saracci R, Hirsch A. Tobacco smoking and gastric cancer: Review and meta-analysis. Int J Cancer. 1997;72:565-73.

27. Buiatti E, Palli D, Decarli A, Amadori D, Avellini C, Bianchi S, et al. A case control study of gastric cancer and diet in Italy. Int J Cancer. 1989;44:611-6.

28. De Stefani E, Correa P, Boffetta P, Deneo-Pellegrini $\mathrm{H}$, Ronco AL, Mendilaharsu $\mathrm{M}$. et al. Dietary 
patterns and risk of gastric cancer: A case-c ontrol study in Uruguay. Gastric Cancer. 2004;7:211-20.

29. Nouraie M, Pietinen P, Kamangar F, Dawsey SM, Abnet CC, Albanes D, et al. Fruits, vegetables, and antioxidants and risk of gastric cancer among male smokers. Cancer Epidemiol Biomarkers Prev. 2005;14:2087-92.

30. Tsugane S, Sasazuki S. Diet and the risk of gastric cancer: review of epidemiological evidence. Gastric Cancer. 2007;10:75-83.

31. Kelley JR, Duggan JM. Gastric cancer epidemiology and risk factors. J Clin Epidemiol. 2003;56:1-9.

32. Brown LM, Devesa SS. Epidemiologic trends in esophageal and gastric cancer in the United States. Surg Oncol Clin N Am. 2002;11:235-56.

33. Engel LS, Chow WH, Vaughan TL, Gammon MD, Risch HA, Stanford JL, et al. Population attributable risks of esophageal and gastric cancers. J Natl Cancer Inst. 2003;95:1404-13.

34. Lindblad M, Rodriguez LA, Lagergren J. Body mass, tobacco and alcohol and risk of esophageal, gastric cardia, and gastric non-cardia adenocarcinoma among men and women in a nested case-control study. Cancer Causes Control. 2005;16:285-94.

35. Lagergren J, Bergström R, Lindgren A, Nyrén O. Symptomatic gastroesophageal reflux as a risk factor for esophageal adenocarcinoma. N Engl J Med. 1999;340:825-31.

36. Dawsey SM, Mark SD, Taylor PR, Limburg PJ. Gastric cancer and H pylori. Gut. 2002;51:457-8.

37. Lambert R. Epidemiology of gastric cancer in the world. Cancéro dig. 2010; 2(1):31-7.

38. Lambert R, Hainaut P, Parkin DM. Premalignant lesions of the esophagogastric mucosa. Semin Oncol. 2004;31:498-512.

39. Chiaravalli AM, Klersy C, Tava F, Manca R, Fiocca $\mathrm{R}$, Capella $\mathrm{C}$, et al. Lower- and higher-grade subtypes of diffuse gastric cancer. Hum Pathol. 2009;40:1591-9.

40. Thibault V. Les adénocarcinomes à cellules indépendantes: une Entité particulière au sein des cancers gastriques ? Human health and pathology. 2014. Available at: http://dumas.ccsd.cnrs.fr/dumas01132575 .

Cite this article as: Ghrissi R, Elghali MA,

Ghammam R, Gouader A, Hamila F, Letaief MR. The changing trends in epidemiological characteristics of gastric adenocarcinoma: a Tunisian center experience. Int Surg J 2016;3:18-22. 